\title{
Challenges and Constraints in Production and Marketing Horticultural Products in Timor Leste*
}

\author{
M.F. Rola-Rubzen, J.A. Janes, V.P. Correia and F. Dias \\ Curtin University of Technology \\ Perth \\ Western Australia
}

Keywords: sustainable horticultural industry, agricultural development, East Timor

\begin{abstract}
This paper describes the farming systems in two horticulture growing regions in Timor Leste and outlines the challenges and constraints faced by farmers in the production and marketing of horticultural products. The paper is based on a wider study of farming systems in Timor Leste. One of the main challenges faced by farmers is the low productivity and quality of the produce. This is due to current farm management and post-harvest practices as well as lack of farm inputs. Product quality is a problem due to poor product handling. Marketing is hampered by the poor transport and road network system, inadequate communication infrastructure, lack of storage facilities, and the lack of a grading and standardisation system in the industry. Given the high local demand for vegetables and the potential for exports, it is important to address these challenges for producers to benefit from market opportunities and increase their incomes. Dealing with these challenges will require a whole value chain approach.
\end{abstract}

\section{BACKGROUND}

A decade after independence, agriculture remains the dominant sector in Timor-Leste, with farming as the main source of income for over 80 per cent of rural households. Although the topography of Timor Leste makes most of the land less than ideal for agriculture, its land is one of the nation's most important resource, with the majority of the population deriving their livelihood from agriculture activities and contributing around 30 per cent of non-oil GDP (UNDP 2006; RDTL 2007). The country has a total land area of approximately 14500 sq km, with 600000 ha suitable for crop and livestock production. Around 174000 ha are estimated to be arable with an additional 124000 ha of bushed gardens (Fang 2006). The average size of cultivable land for each farmer is about 0.9 ha. Most of the land is not used intensively and there is potential to increase crops, pastures, and livestock production.

Most farmers in Timor Leste (also known as East Timor) are subsistence farmers who mainly produce for self-consumption; only selling the small surplus they have (GoTL 2003). They generally use unpaid family and communal labour, small plots of land, basic tools, and few non-farm inputs and rely mainly on rain water. House gardens of typically 0.25 hectares, are found around most rural dwellings, with some fruit trees in surrounding areas. Some farm households also raise a few small animals such as chicken and ducks.

Due to the dependence of a large number of East Timorese on agriculture for their livelihood, the Government of Timor Leste (GoTL) has made the development of its agricultural sector a top priority. One area identified for accelerated growth is the development of high-value crops such as fruits and vegetables (MAFF 2004). 


\section{POTENTIAL FOR HORTICULTURE PRODUCTION IN TIMOR LESTE}

There are some clear advantages for developing the horticulture sector in Timor Leste. Firstly, some areas in Timor Leste such as Aileu, Maubisse, Hatubuilico and Ermera are suitable to horticulture production. Favourable climatic and soil conditions, the temperature and rainfall pattern mean that farmers can plant at least two crops a year. For instance, in Aileu and other horticulture production areas, farmers plant the main food crop such as rice or maize in mid November and then plant vegetables from March to April towards the end of the monsoon when temperatures start to decrease.

Secondly, the country has benefited from international aid agencies and external donors and has received much needed support for the agricultural sector. In particular, one program that directly targeted the horticulture sector is the USAID-funded project on private sector development. In 2006, Development Alternatives, with funding from USAID introduced the Desenvolve Setor Privadu (DSP) or Private Sector Development Project. DSP designated special horticulture areas (SHA) and worked with farmers and the private sector to improve production of horticultural crops. DSP's approach was to work along the whole supply chain to improve the quantity and quality of vegetables to meet market demand and compete with imported vegetables, which were largely favoured by supermarkets in Dili. This initiative has had promising results in improving horticultural production in the SHAs in recent years (Correia et al. 2010, DAI 2008).

Thirdly, there is currently a market for fruits and vegetables locally. A demand study conducted in 2006 by the Private Sector Development Project of USAID (DSP-USAID) in Dili estimated the demand for vegetables to be about 38.1 metric tons per month in Dili (DSP-USAID 2006). The market for vegetables in Timor Leste is however segmented. The expatriate community and hotels and restaurants that service the large number of foreign nationals working with the UN and aid agencies have created a market for western vegetables such as lettuce, cabbage, carrots, chilli, snow peas, tomatoes, potatoes and shallots. The local population, on the other hand, buys indigenous vegetables such as kangkung, pumpkin, mustard etc. which have been traditionally consumed by East Timorese households.

According to MAFF (2007), the production of vegetables in Dili is about 630 metric tons per year. Total production of vegetables in Timor Leste in 1997 and 2007 is shown in Table 1 below. As shown in the table, both area and production volumes for some vegetables have increased between 1997 and 2007, but have decreased for others. For example, the volume of production of beans has more than doubled from 1997 to 2007 while cabbage production has decreased by almost half in the same period.

Finally, due to its proximity to neighbouring countries such as Indonesia, Australia and Singapore, there is a potential for exporting selected horticultural products. According to De Boer et al. (2004), due to the Timorese production conditions, there are potential opportunities for East Timor to export horticulture products, particularly snow peas, to Australia and Singapore, although Rahim (2005) claimed that export horticulture products were simply not feasible at that time.

\section{OBJECTIVE}

The objective of this paper is to examine the farming systems of selected horticultural production areas and identify the challenges and constraints faced by farmers in terms of production and marketing of their horticultural produce. The potential of these areas for horticultural production will not be examined as these areas have already been identified as horticultural growing areas in Timor Leste. Rather, the focus is on looking at the challenges and constraints faced by farmers in their quest to increase production and household incomes. Understanding the bottlenecks faced by farmers will provide insights as to what is needed to 
support the development of a sustainable horticulture sector in Timor Leste to increase the production and income of farmers.

\section{METHODOLOGY}

The sites chosen for the study are the localities of Aileu and Maubisse. The town, Aileu is located in the district of Aileu, while Maubisse is located in the district of Ainaro, both considered as potential areas for horticulture production in Timor Leste. The study involved interviews with farmers, government agencies, NGOs and other stakeholders. Both primary and secondary data were gathered. Data gathering methods employed included faceto-face interviews, rapid rural appraisals and a review of related literature. For the survey, the main respondents in this study were the farming households.

Data were collected through surveys of 120 farming households per district, for a total of 240 farming households randomly selected from Aileu and Maubisse. In addition, rapid rural appraisals (RRA) were conducted in each district. Included in the RRA were semistructured interviews with community leaders, government agencies and local and international NGOs to determine institutional structures, resource base and organizations in the area.

Data analysis included both qualitative and quantitative analysis. Statistical analysis employed included descriptive analysis such as frequency tabulations. The questionnaire was written in Bahasa Indonesia and pre-tested and revised accordingly. During interviews, the appropriate language was used (either Bahasa Indonesia or Tetum). The survey was conducted in June and July 2007.

This paper mainly focuses on the challenges in production and marketing of horticultural products in Aileu and Maubisse.

\section{DESCRIPTION OF STUDY AREAS}

Aileu and Ainaro districts are known horticulture production centres in Timor Leste. Farmers in the area have a background in horticultural production and have been growing vegetables for a long time, even before independence from Indonesia.

Aileu is situated in the north-western part of Timor Leste. The total land area is about 729 sq km with a population of about 36889 people (Graven \& Neupert 2004). The topography is mostly sloping and mountainous. The temperature is approximately $20-23^{\circ} \mathrm{C}$ with an altitude of more than $869 \mathrm{~m}$ above sea level. The rainy season starts in November and the dry season begins in June or July. Farmers in this area produce maize, coffee, oranges, potatoes and vegetables. In addition, Aileu has extensive horticulture because of its cool climate, good soils and favourable rainfall throughout most of the year.

Ainaro on the other hand, is located in the southwest part of the country with a total land area of 797 sq km and a population of about 54000 people (Graven \& Neupert 2004). Ainaro has an abundance of water because of the presence of a river and fertile terrain for agriculture. It has coastal areas along the Timor Sea, but also mountainous zones, including the highest point in Timor Leste, Mt Ramelau (2,960 $\mathrm{m}$ above sea level). The topography of Ainaro is mostly mountainous and sloping with an elevation of 426 - $1432 \mathrm{~m}$ above sea level. The temperature is about $20-24^{\circ} \mathrm{C}$. The main market in Ainaro district is Maubisse by virtue of the fact that it is situated two hours from Dili and is before the confluence of the road that leads off to Ainaro, Suai and Same. Maubisse and Hatubuilico are sub-districts of Ainaro well known as horticulture production areas in Timor Leste. Farmers in Ainaro produce coffee, vegetables, potatoes and fruits. 


\section{RESULTS AND DISCUSSION}

The respondents in the survey are farming households from Aileu and Maubisse. As shown in Table 2, a total of 240 farmers were interviewed. Approximately 82 per cent of respondents in Aileu are male and 18 per cent are female. The average age of respondents in Aileu is 41.8 and the household size is about 6.8.

In Maubisse, about 81 per cent of respondents are male and 19 per cent are female. The average household size is 6 and the average age of farmer respondents is 43.7 years.

\section{Farming Systems}

On average, the farm size per household in Aileu and Maubisse is 2.1 and 1.9 ha, respectively. The distribution of farm size is shown in Table 3.

As shown in the table, most respondents both in Aileu and Maubisse own above 1 ha. In Aileu, more than half of respondents own between 1.01 ha to more than 2 ha. However, most farmers only utilise less than 0.5 ha of their land for crop production. This is because of lack of seeds, low levels of input use (e.g., fertiliser) and poor access to markets. Farmers however indicated that given the right seeds, assistance and other inputs, they will increase production to meet both their own consumption and sell to the market.

The predominant land tenure in these two districts is private ownership. Most of the land is classified as upland rainfed. The dominant crops in Aileu are horticulture crops, coffee, cassava and maize. Meanwhile, in Maubisse, crop production is dominated by coffee, horticulture crops, maize and paddy rice. These two localities are located in high altitude areas with cool climatic conditions making them suitable for coffee and horticultural crops.

The basis for farmers' decision on what crops to plant in a specific season is mostly based on weather conditions, family needs and tradition. Customs or traditions still significantly influences the decisions of farmers on what crops to grow in a particular season. For example, maize and cassava are only grown by farmers from November/ December each year as has been the tradition. Although technically farmers can also grow maize or cassava in May or June because of the availability of water throughout the year, farmers in the area do not grow maize in other times of the year except in November or December, mainly because this is the customary practice.

Most farmers do not use fertilisers or pesticides. The results of the study revealed that only about 5.4 and 1.9 per cent of respondents in Aileu and Maubisse, respectively, use inorganic fertilizer and pesticides in their farm.

In terms of labour use, most of the respondents rely on family members for farm labour. They do not use inputs other than seeds and their own labour and only a small percentage of respondents exchange their labour. The exchange of labour only occurs for some activities such as planting and harvesting for maize and paddy rice. None of the respondents hire labour because of the lack of capital and also the tradition where they prefer to help each other rather than pay someone to work in their farm.

Horticultural crops grown by respondents both in Aileu and Maubisse include cabbages, carrots, beans, mustard, tomatoes, potatoes, onions, garlic, snow peas, cucumber, pumpkin, chilli, lettuce and shallot. These horticultural crops grow well in these areas however the productivity is very low due to the lack of seeds and other inputs as well as the prevalence of traditional crop management methods.

Recently, new crop varieties were introduced by DSP to some farmers as part of the DSP-USAID project. The varieties chosen were those that have a high demand in Dili markets. These varieties include Chinese cabbage, kale, cauliflower, Japanese cucumber, purple eggplant, cherry tomatoes, tomatoes (red crown), carrots and Italian parsley. However, only participant farmers were able to access seeds for these vegetables. 
Peak harvesting occurs in early June to mid August. A variety of vegetables and spice crops are grown for home consumption as well as for income generation, although the transportation network limits market access for perishable commodities (De Boer et al. 2004).

\section{Marketing and Supply Chains for Vegetables}

Unlike in many areas in Timor Leste, participation in the commercial sector in Aileu and Maubisse is relatively high. When asked about whether they sell their crops and livestock, more than 60 per cent of respondents both in Aileu and Maubisse said they sell some of their produce to the market. Most of their products are sold through local markets, district markets and wholesalers. Lack of transportation and the cost of transporting products, the lack of access to other major markets (e.g., Dili market) are the main reasons most farmers rely on local and district markets when selling their produce. Farmers also indicated that they have no information about prices and market demand outside local markets. They are mainly price takers and their primary source of price information are their buyers, which can lead to price manipulation by the buyers.

The supply chains of vegetables in Aileu and Maubisse are shown in Figures 1. As shown in the figures, there are several players involved in the supply chain of horticultural products in Aileu and Maubisse before the product reaches consumers. For example in Aileu, from producers, the product goes to the local market. Traders then buy the products and sell them in the district and Dili markets. In Dili markets, the products go through the retailers before finally reaching consumers. In some cases, traders (e.g. Zero Star) buy products from farmers and sell directly to high end consumers in Dili. Zero Star is one of the few private businesses dealing with vegetable products that has a cool chain management system in place. In some cases, farmers sell directly to Dili markets where vegetables go through retailers and finally consumers. The most common channel however in these two districts is depicted by the black line in the diagrams, where the product flow is from producers - local market - traders - Dili or district markets - retailers - consumers (Figures 1).

According to respondents, the majority of their output is sold to the market. However, lack of transportation, the cost of transporting vegetables, lack of access to markets and the low prices received by farmers deter farmers from increasing their production.

\section{CONSTRAINTS AND CHALLENGES}

As with most of the agriculture sector in Timor Leste, the horticulture sector is faced with many challenges and constraints in production and marketing. Horticultural production is still characterised by low levels of farm output, low productivity, fluctuations in production and poor product quality.

In marketing, farmers are faced with high marketing costs, lack of access to main markets and low prices for their produce. Moreover, the quality of local produce is considered inferior to imported vegetables, thus prices fetched for locally produced vegetables are also lower. This is exacerbated by a lack of grading and standardisation system, hence farmers are unable to take advantage of any price differentiation.

The low production, productivity levels and poor quality of vegetables can be attributed to the following constraints faced by farmers.

\section{Low Input Use}

One of the main reasons for the poor productivity is the low levels of input use in the farm. As mentioned above, there is little input use by farmers apart from seeds and labour. Very few farmers apply fertilisers and pesticides. This in turn is due to the low levels of income and low purchasing power of farm households. Most farmers still rely on traditional seeds. Moreover, critical inputs such as good (certified) seeds and inorganic fertilisers are not 
readily available. Yet, it is well known that these inputs have a significant influence on crop yield.

Farmers in these two districts also face widespread occurrence of pest and diseases which attack their vegetable plots. However, without the ability to purchase pesticides, they are unable to deal with pests and diseases, hence resulting to low yields. DSP-USAID farmer participants have access to seeds, fertilisers and pesticides, but these inputs are not available to non-participant farmers.

\section{Lack of Finance}

One of the stumbling blocks for farmers is the lack of capital to purchase inputs and invest in farm improvements in the farm. The survey of living standards in Timor Leste reveals that poverty and unemployment are widespread, with over 40 per cent of the population living below the national poverty line of US\$0.55 per capita per day (RDTL 2007). With the lack of cash to purchase inputs and the lack of access to credit, it is difficult if not impossible for farmers to increase production and productivity of their crops.

\section{Lack of Technical Knowledge and Skills}

The use of traditional technologies is widespread and continues to constrain this sector. Although farmers have a background in horticultural production, they still use traditional crop management practices and are not familiar with modern farming methods. The level of schooling is low and there is a high rate of illiteracy particularly in rural areas. These affect the ability and skills of farmers to adopt new technologies and innovations. There is no extension service to assist farmers to improve their technical skills as well as disseminate market information.

\section{Lack of Information}

Lack of market information is often quoted as a major reason why farmers are not realising better prices for their produce. There is no extension service nor market information system to arm farmers with knowledge of prices and potential markets. Often, their main source of price information apart from the buyers are other farmers or friends who have just returned from the market that day.

Moreover, farmers have very little or no power of arbitrage in the market and have limited choice as to which markets they can sell into. Consequently, as previously mentioned, they often receive whatever price they are offered.

\section{Poor Road and Transport System}

Other marketing constraints faced by farmers are the poorly maintained agricultural infrastructure such as farm access roads and the poor road infrastructure network from the district to main market centres. Rural roads are important for delivering goods and services required for agricultural production and transporting outputs to markets and processing facilities. However, the rural roads in Maubisse and Aileu are mostly in bad condition. This presents a major constraint in improving agricultural productivity in general as it makes the transaction cost of doing business high for farmers.

In addition, the availability and cost of transport is another constraint in marketing products. In both Aileu and Ainaro districts, the primary form of transport for most people is by foot and horse. People sometimes walk up to six hours to get their produce to the market. Moreover, while proper storage is important due to the highly perishable nature of vegetables, there are no cold storage facilities in the districts resulting to poor product quality. 


\section{CONCLUSION: THE WAY FORWARD}

Despite the constraints faced by farmers, Timor Leste has the potential to increase agricultural production for almost all its traditional food and export crops as well as for new potential exports such as horticultural crops and aquaculture products (NCRD 2008). Agricultural production can be increased by area expansion and/ or by improving productivity levels. As pointed in the paper, much of the land is currently farmed on a low input, low output basis but is suitable for more intensive cultivation.

One of the main challenges faced by farmers is the low productivity and quality of their produce. This is due to current farm management and post-harvest practices, lack of farm inputs, lack of finance and poor knowledge of modern techniques of horticulture production and post production. Similarly in marketing, farmers encounter a host of problems including lack of information on prices and markets, limited transportation as well as the high transport cost. Product quality is a problem because of poor product handling. Moreover, while proper storage is important due to the highly perishable nature of vegetables, there are no cold storage facilities in these areas. Given the high local demand for vegetables and the potential for exports, it is important to address these challenges for producers to benefit from market opportunities and increase their incomes.

One of the threats facing the horticultural industry in Timor Leste is the large volume of vegetable imports, mostly coming from Australia. Imported vegetables are of high quality and are preferred by most supermarkets. The challenge is how local growers can compete with these imported vegetables to capture the high-end market such as the expatriate community as well as the emerging middle class. This can be done by removing the bottlenecks faced by farmers.

It is evident that the problems occur along the entire supply chain - in production at the farm, in processing/ product handling, and transporting till the product reaches the market. Hence, these issues can be dealt with by improving the supply chain and engaging the players from farmers, to processors, private traders and buyers. Enhancing national agricultural production and overcoming the present inability of local producers to compete with imported products requires the combined effort of the government and the private sector. For instance, apart from the badly needed improvements in roads and infrastructure, there is a need to improve the availability of inputs such as seeds and fertilisers so farmers can purchase them when needed. Farmers also need training in modern production techniques and product handling. Processors need to learn about efficient ways of packaging and product handling. All players need to be aware of food safety issues and how to handle the vegetables properly to reduce post-harvest losses.

The experience of DSP-USAID has shown that farmers can increase productivity levels, given access to agricultural inputs and the right skills to grow their products. But alongside this, it is important that farmers are able to link with markets. Improvements in the road conditions and other rural infrastructure such as storage and communication facilities will make it easier for farmers to reach markets and improve the terms of trade of farmers. Moreover, there is a need to change farmers' attitudes towards market-oriented farming. The adjustment to a market-based agricultural system, while proving difficult, will inevitably happen if farmers can see that growing vegetables for commercial purposes is worthwhile. This will occur if they can see that there is a demand for their product and that horticultural production is a profitable enterprise. Likewise, as incomes of East Timorese increase as the country rebuilds, it is likely that demand for high valued vegetables will also increase. Experience from other countries has shown that economic development often leads to a change in consumer demand toward high-valued agricultural commodities (Rola-Rubzen and Hardaker 2003, Rosegrant et al. 2001; Goletti 1999). Hence in the medium to long run, there is scope for market-oriented production of fruits and vegetables. However, given that the 
constraints occur in different components of the supply chain, concentrating developments in one aspect of the supply chain exclusively (either in production or marketing) is not likely to solve the problems of the (fruits and vegetables) horticultural industry. Hence for the East Timorese people to benefit, the horticultural industry should adopt a whole value chain approach to development. This will require partnership between farmers, the government and the private sector.

\section{Literature Cited}

Correia, V.P. and Rola-Rubzen, M.F. 2010, Linking Farmers to Markets in Timor Leste: The Case of Dezenvolve Seitor Privadu (DSP), Paper presented at the AARES 54th Annual Conference, 8-12 February, Adelaide.

DAI, 2008, Dezenvolve Sétor Privadu, Annual Report July 2007 - July 2008, USAID, Dili.

DeBoer, J., Brown, A., Costa, A., Verdial, O., Correia, P. \& Gusmao, M. 2004, Horticulture Production Feasibility Study for Timor Leste, DAI-USAID, Dili Timor Leste, pp.3 (unpublished manuscript).

DSP-USAID, 2006, Summary Report: Demand Study for Horticulture Products in Dili, DSPUSAID, Dili (unpublished manuscript).

Fang, C. 2006, Timor Leste Pre-Crisis Market Profile, WFP-SENAC project, Dili.

Goletti, F. 1999, Agricultural Diversification and Rural Industrialisation as a Strategy for Rural Income Growth and Poverty Reduction in Indochina and Myanmar, Markets and Structural Studies Division Paper 30, International Food Policy Research Institute, Washington, D.C.

GoTL, 2003, Timor Leste Poverty Assessment: A New Nation Emerging from Deprivation, Government of Timor Leste, Dili.

Graven, D. \& Neupert, R. 2004, Census of Population and Housing in Timor Leste, First Edition, UNFPD \& RDTL, Dili.

MAFF, 2004, Policy and Strategic Framework, Ministry of Agriculture, Forestry and Fisheries, Dili, East Timor.

MAFF, 2007, Realizacoes do Ministerio da Agricultura, Florestas e Pescas, relatorio de cinco anos (2002 - 2007), Ministry of Agriculture, Forestry and Fisheries, Dili.

NCRD, 2008, Timor Leste: State of the Nation Report, National Commission for Research and Development, Ministry of Economy and Development, Democratic Republic of Timor Leste, Dili.

Rahim, K.K. 2005, Market Feasibility Study for AMCAP, UNOPS, Bangkok.

RDTL, 2007, Timor Leste survey of living standards, Democratic Republic of Timor Leste, Dili.

Rola-Rubzen, M.F., Correia, V.P., Salsinha, N. and Janes, J. (eds.) 2010. Farming systems in Timor Leste, Research Report, Curtin University of Technology and Universidade Nacional de Timor Loro Sae, Perth (draft manuscript).

Rola-Rubzen, M.F., and Hardaker, J. B. 2003, Making Agricultural Diversification Work for the Poor: The Challenge for the Asia-Pacific Region, Consultancy Report, UN-FAO CUREMIS, Food and Agricultural Organisation of the United Nations, Caracalla, Italy.

Rosegrant, M., Paisner, M.S., Meijer, S. and Witcover, J. 2001, Global Food Projections to 2020: Emerging Trends and Alternative Futures, 2020 Vision, International Food Policy Research Institute, Washington, D.C.

UNDP, 2006, Timor Leste Human Development Report 2006: The Path Out of Poverty, United Nations Development Programme, Dili. 
Table 1. Production of horticulture crops in Timor Leste (1997 \& 2007).

\begin{tabular}{|c|c|c|c|c|}
\hline \multirow[t]{2}{*}{ Crops } & \multicolumn{2}{|c|}{ Area planted (ha) } & \multicolumn{2}{|l|}{ Production(t) } \\
\hline & 1997 & 2007 & 1997 & 2007 \\
\hline Cabbages & 611 & 355 & 4919 & 2859 \\
\hline Carrots & 88 & 89 & 619 & 644 \\
\hline Snow peas & 5023 & 132 & 2915 & 356 \\
\hline Mustard & 268 & 416 & 1900 & 2739 \\
\hline Shallot & 234 & 415 & 757 & 1184 \\
\hline Garlic & 228 & 326 & 652 & 734 \\
\hline Beans & 496 & 6025 & 1382 & 3680 \\
\hline Tomato & 222 & 92 & 920 & 162 \\
\hline Chilli & - & 75 & - & 262 \\
\hline Lettuce & - & 47 & - & 25 \\
\hline Potato & 530 & 953 & 1348 & 800 \\
\hline Kangkung & 83 & 130 & 319 & 487 \\
\hline Cucumber & 68 & 91 & 447 & 583 \\
\hline
\end{tabular}

Source: Ministry of Agriculture and Forestry, 2007

Table 2. General characteristics of respondents.

\begin{tabular}{lll}
\hline Characteristic & Aileu & Maubisse \\
\hline No. of farm households interviewed & 120 & 120 \\
No. of male respondents male (\%) & $99(82.5 \%)$ & $97(80.8 \%)$ \\
No. of female respondents male (\%) & $21(17.5 \%)$ & $23(19.2 \%)$ \\
Average household size & 6.8 & 6 \\
Average age & 41.8 & 43.7 \\
\hline
\end{tabular}

Table 3. Farm size of respondents in Aileu and Ainaro.

\begin{tabular}{lrr}
\hline $\begin{array}{c}\text { Farm size } \\
\text { (ha) }\end{array}$ & $\begin{array}{l}\text { Aileu } \\
\text { (\%) }\end{array}$ & $\begin{array}{c}\text { Maubisse } \\
(\%)\end{array}$ \\
\hline & & \\
$<0.25$ & 8.1 & 0.6 \\
$0.26-0.50$ & 15.3 & 3.1 \\
$0.51-1.00$ & 19.8 & 12.4 \\
$1.01-2.00$ & 27.0 & 43.5 \\
$>2.00$ & 27.9 & 40.4 \\
\hline
\end{tabular}

\section{Figures}




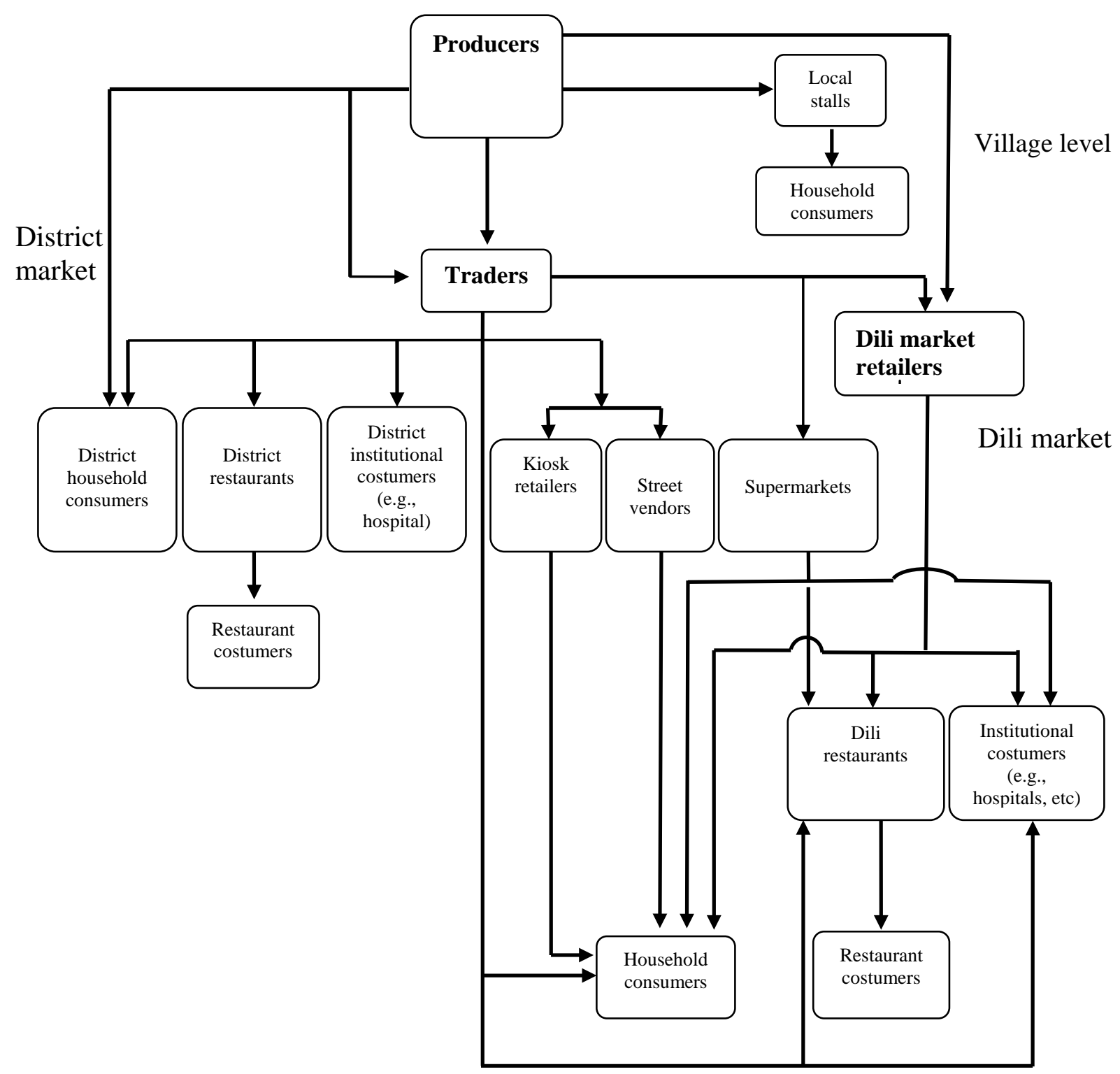

Figure 1. Supply chain for horticulture produce in Aileu \& Maubisse 